\title{
The Development of Manual Skills of Pupils with Mild Intellectual Disability
}

\author{
Pavel Zikl \\ Institute of Primary and Pre-primary Education \\ Faculty of Education, University of Hradec Králové \\ Hradec Králové, Czech Republic \\ pavel.zik1@uhk.cz
}

\begin{abstract}
This paper presents the results of research aimed at comparing the levels of manual skills of pupils with a mild intellectual disability (MID) with those of intact children. More importantly, it aims at the changes which should occur during attendance of the first grade of primary school. A simple disassembly and assembly of a construction kit by the pupils was used for data collection. The research sample consisted of 257 children with an average age of 8 years (in the first phase of primary education), or 10.5 years (in the second phase of primary education). The results show the differences between the two groups of pupils when completing tasks with varying degree of difficulty, and the changes in the performance between younger and older pupils.
\end{abstract}

Keywords-mild intellectual disability, manual skills, motor activity, pupils with special needs

\section{INTRODUCTION}

Improving the level of manual skills is an important objective in the education of pupils with intellectual disability. The relevant practical subjects have been included in their schedule from the first year of practical primary school. As stated in the curriculum (Framework Education Programme for Elementary Education - supplement for education of pupils with MID), the educational area 'Man and the world of work' is one of the main educational areas in the elementary education of pupils with MID.

The imperfections of children with intellectual disability are inevitably reflected in their manual activities whenever it is necessary employ deeper thinking (e.g. analysing a shape of a piece in the construction kit and planning its installation). Slow motor development has also a negative impact here. These children usually suffer from imperfect locomotion, balance and manual skills. Therefore, practical school subjects are considered to be important for these children because they prepare them for manual professions, which most of them will perform as adults without any help and with similar results as the intact people (see e.g. [1]).

Knowing the actual level of manual skills during the attendance of primary school is an important starting point for the planning of appropriate teaching methods and selecting appropriate tools. It is also important for the integration of these pupils in ordinary schools, which has been recently emphasized. Manual activities may be an area where these children will achieve the same results as other children (not including Czech language or math). By supporting such activities we can assist their integration, and prevent social exclusion and negative impacts on their mental condition. (E.g. their self-evaluation, etc.).

In our previous research, we focused on the comparison of the level of motor skills of pupils with MID and mentally intact pupils using standardized tests of fine and gross motor skills (Jebsen Taylor Hand Function Test, [2]; Test of Gross Motor Development, [3]). In the research presented here, our aim was to compare the development of manual skills of pupils with MID during the attendance of the primary school.

\section{METHODOLOGY AND DESCRIPTION OF THE RESEARCH SAMPLE}

For determining the level of manual skills, we chose a simple disassembly and assembly tasks using construction kits. We were looking for activities that were in the curriculum for both groups of children (younger and older) and that the children were familiar with (Framework Education Programme for Elementary Education [4], FEP for EE - supplement for education of pupils with MID [5]). Individual tests were verified by a preliminary research. Prior to the testing, the pupils got a trial task. In the test, they received only the parts they needed for the assembly of the product, instead of having to select from many similar parts.

The tasks were compiled with different levels of difficulty:

- Task 1: focused on mechanical manual activity (simple disassembly),

- Task 2: focused on the assembly based on a simple model (a product composed of several parts whose assembly required only a simple analysis of shapes, selection of the necessary parts and assembly)

- Task 3: focused on the work according to a manual (instructions consisting of pictures were needed to assemble a spatial product).

Statistical calculations were carried out in the NCSS2000 program. The Student's t-test and Mann-Whitney nonparametric test had been chosen for the hypotheses testing (the samples did not have a normal distribution). The significance level $\alpha=0.05$ was chosen for the testing.

257 pupils participated in the research - 177 pupils in 4th and 5 th year (2nd phase of primary education, average age 10.5 
years) and 80 pupils in 1 st -3 th years (first phase, average age 8 years) of primary schools (intact population) and practical primary schools (pupils with MID, dg. F70, [6]). A detailed description of the sample is shown in tables 1 . and 2 .

TABLE I. RESEARCH SAMPLE - 1ST PHASE OF PRIMARY SCHOOL

\begin{tabular}{|l|c|c|c|c|}
\hline \multicolumn{5}{|c|}{ Research sample } \\
\hline \multirow{2}{*}{\begin{tabular}{l} 
Number $\begin{array}{l}\text { Pupils with MID } \\
\text { children }\end{array}$ \\
\cline { 2 - 5 }
\end{tabular}} & \multicolumn{2}{|c|}{40} & \multicolumn{2}{c|}{ intact pupils } \\
\cline { 2 - 5 } & 24 & 16 & 16 & 24 \\
\hline $\begin{array}{l}\text { Age (average; } \\
\text { standard } \\
\text { deviation) }\end{array}$ & $\begin{array}{c}7.90 \\
(0.50)\end{array}$ & $\begin{array}{c}7.91 \\
(0.67)\end{array}$ & $\begin{array}{c}7.34 \\
(0.91)\end{array}$ & $\begin{array}{c}8.00 \\
(0.69)\end{array}$ \\
\hline $\begin{array}{l}\text { There is not a statistical difference between boys and girls. Different } \\
\text { ratio of boys and girls do not distort the outcome of the research. }\end{array}$ \\
\hline
\end{tabular}

TABLE II. RESEARCH SAMPLE - 2ND PHASE OF PRIMARY SCHOOL

\begin{tabular}{|l|c|c|c|c|}
\hline \multicolumn{4}{|c|}{ Research sample } \\
\hline & \multicolumn{2}{|c|}{ Pupils with MID } & \multicolumn{2}{c|}{ intact pupils } \\
\hline \multirow{2}{*}{$\begin{array}{l}\text { Number of } \\
\text { children }\end{array}$} & \multicolumn{2}{|c|}{97} & \multicolumn{2}{c|}{80} \\
\cline { 2 - 5 } & boys & girls & boys & girls \\
\cline { 2 - 5 } & 61 & 36 & 42 & 38 \\
\hline $\begin{array}{l}\text { Age (average; } \\
\text { standard } \\
\text { deviation) }\end{array}$ & $\begin{array}{c}10,5 \\
(0,79)\end{array}$ & $\begin{array}{c}10,5 \\
(0,98)\end{array}$ & $\begin{array}{c}10,1 \\
(1,27)\end{array}$ & $\begin{array}{c}10,5 \\
(1,02)\end{array}$ \\
\hline
\end{tabular}

There is not a statistical difference between boys and girls. Different ratio of boys and girls do not distort the outcome of the research.

We determined following hypotheses:

- H1: Pupils with MID will improve as much as the intact pupils between the 1 st and 2 nd phase of primary school.

- H2: Difference between the pupils with MID and intact pupils will not increase between the 1st and 2nd phase of primary school.

\section{RESULTS OF THE RESEARCH}

In tables 3 - 5 the results of each task by age of pupils are presented (1st and 2 nd phase of primary school, i.e. age 8 and 10.5 years in average). [7] [8] [9]

As we had assumed, pupils with MID had worse results than intact pupils. This difference was deepening with increasing difficulty of the tasks. In simple mechanical disassembly pupils with MID were worse by about $1 / 4-1 / 3$. In slightly more demanding tasks, which also required a higher concentration (assembly using a model, assembly using instructions on pictures), the difference increased to $2 / 3$ - more than double (for details see tables 3-5). A slightly higher dispersion of results for children with MID can be seen but we did not get more extreme values than we had expected. The best pupils in both groups had virtually the same result but only few pupils with MID achieved the best results.
TABLE III. TASK 1 (SIMPLE DISASSEMBLY)

\begin{tabular}{|l|c|c|c|c|}
\hline \multicolumn{5}{|c|}{ Task 1 (simple disassembly) } \\
\hline & \multicolumn{2}{|c|}{$\begin{array}{c}\text { 1st phase of primary } \\
\text { school (younger pupils) }\end{array}$} & \multicolumn{2}{|c|}{$\begin{array}{c}\text { 2nd phase of } \\
\text { primary school } \\
\text { (older pupils) }\end{array}$} \\
\hline & MID & intact & MID & intact \\
\hline Average (seconds) & 115 & 85 & 100 & 78 \\
\hline Standard deviation & 52.8 & 29.8 & 56.4 & 49.4 \\
\hline Median & 103 & 85 & 83 & 68 \\
\hline $\begin{array}{l}\text { Pupils with MID worse } \\
\text { by \% }\end{array}$ & & $35.3 \%$ & $28.2 \%$ \\
\hline
\end{tabular}

TABLE IV. TASK 2 (ASSEMBLY USING A MODEL)

\begin{tabular}{|l|c|c|c|c|}
\hline \multicolumn{5}{|c|}{ Task 2 (assembly using a model) } \\
\hline & \multicolumn{2}{|c|}{$\begin{array}{c}\text { 1st phase of primary } \\
\text { school (younger pupils) }\end{array}$} & \multicolumn{2}{c|}{$\begin{array}{c}\text { 2nd phase of } \\
\text { primary school } \\
\text { (older pupils) }\end{array}$} \\
\hline & MID & intact & MID & intact \\
\hline Average (seconds) & 243 & 124 & 145 & 84 \\
\hline Standard deviation & 178.55 & 62.25 & 75.2 & 41.4 \\
\hline Median & 198 & 117 & 124 & 69 \\
\hline $\begin{array}{l}\text { Pupils with MID worse } \\
\text { by \% }\end{array}$ & \multicolumn{2}{|c|}{$96.0 \%$} & $72.6 \%$ \\
\hline
\end{tabular}

TABLE V. TASK 3 (ASSEMBLY USING A MANUAL)

\begin{tabular}{|l|c|c|c|c|}
\hline \multicolumn{5}{|c|}{ Task 3 (assembly using a manual) } \\
\hline & \multicolumn{2}{|c|}{$\begin{array}{c}\text { 1st phase of primary } \\
\text { school (younger pupils) }\end{array}$} & $\begin{array}{c}\text { 1st phase of primary } \\
\text { school (younger } \\
\text { pupils) }\end{array}$ \\
\hline & MID & intact & MID & intact \\
\hline Average (seconds) & 555 & 255 & 337 & 202 \\
\hline Standard deviation & 217.76 & 82.13 & 211 & 81.2 \\
\hline Median & 478 & 241.5 & 284 & 202.5 \\
\hline $\begin{array}{l}\text { Pupils with MID worse } \\
\text { by \% }\end{array}$ & \multicolumn{2}{|c|}{$117.6 \%$} & \multicolumn{2}{c|}{$66.8 \%$} \\
\hline
\end{tabular}

At this stage of the research we have focused mainly on the changes in manual skills, which should occur during the attendance of primary school.

The results are presented in table VI. and figure I.

TABLE VI. DIFFERENCE BETWEEN THE RESULTS IN 1 ST AND
2ND PHASE OF PRIMARY SCHOOL

\begin{tabular}{|c|c|c|}
\hline \multicolumn{3}{|c|}{$\begin{array}{c}\text { Difference between the results in 1st and 2nd } \\
\text { phase of primary school }\end{array}$} \\
\hline & MID & intact \\
\hline \multicolumn{3}{|c|}{ Task 1 (simple disassembly) } \\
\hline Differece (seconds) & 15 & 7 \\
\hline
\end{tabular}




\begin{tabular}{|l|c|c|}
$\mid \begin{array}{l}|l| \\
\text { Imrovement by \% }\end{array}$ & $13.0 \%$ & $8.2 \%$ \\
\hline \multicolumn{2}{|l|}{ Task 2 (assembly using a model) } \\
\hline Difference (seconds) & 98 & 40 \\
\hline Improvement by \% & $40.0 \%$ & $32.3 \%$ \\
\hline Task 3 (assembly using a manual) \\
\hline Difference (seconds) & 218 & 53 \\
\hline Improvement by \% & $53.0 \%$ & $20.8 \%$ \\
\hline
\end{tabular}

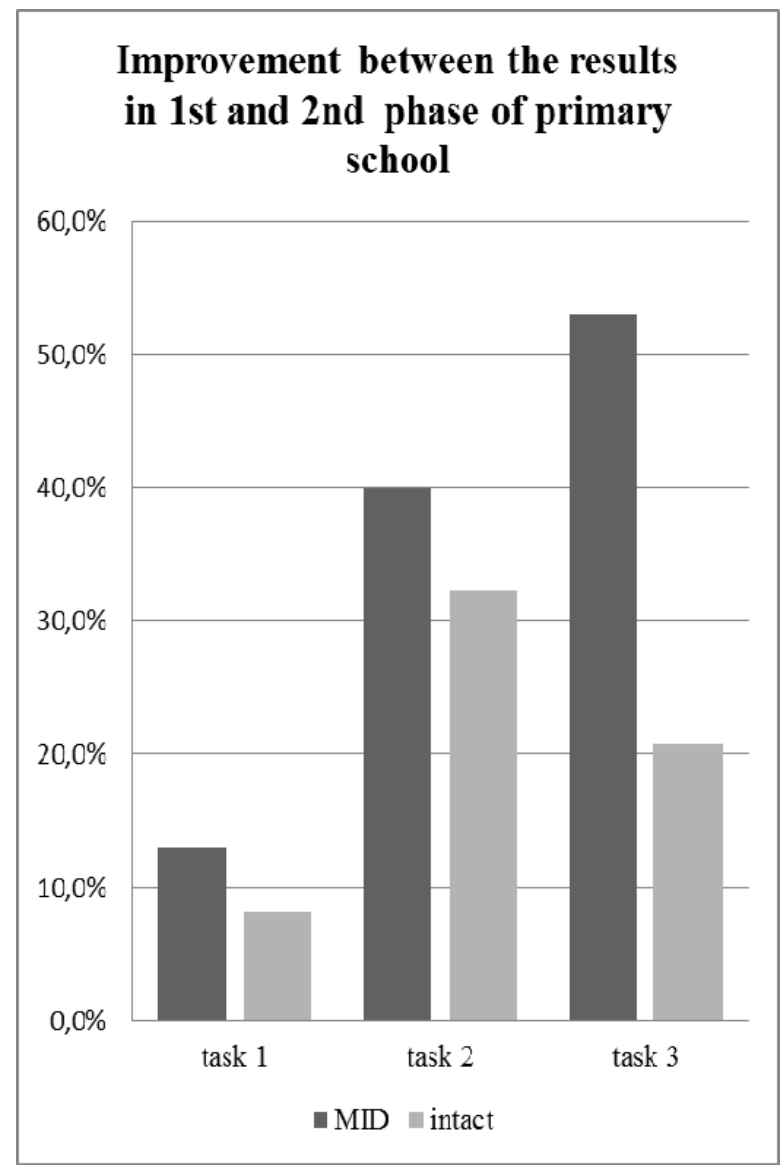

FIGURE I. DIFFERENCE BETWEEN THE RESULTS IN 1ST AND 2ND PHASE OF PRIMARY SCHOOL

Both groups of pupils have improved their performance but contrary to our expectations the pupils with MID have improved more than the intact pupils. The first hypothesis has not confirmed. Pupils with MID were progressing more in the more demanding tasks. While in the simple disassembly the improvement was $13 \%$, in assembly using a model and assembly using a manual the improvement was $40 \%$ and $53 \%$.

The second hypothesis has been confirmed. The difference between older pupils with MID and older intact pupils did not increase; on the contrary, it decreased. As can be seen in tables 1 - 3 (the last line), the differences for younger pupils in individual tasks were $35.3 \%, 96 \%$ and $117.6 \%$. For older pupils, the differences decreased to $28.2 \%, 72.6 \%$ and $66.8 \%$.
Despite the positive development, the difference remains relatively high; this applies also to the easiest task. Moreover, pupils with MID were making more mistakes, i.e. they used a part wrongly or mixed up the parts. The children made almost no mistakes in the first task (disassembly) but in the other two tasks the pupils with MID made more mistakes. In the second task $33 \%$ of children with MID made a mistake as opposed to $5 \%$ of intact children's mistakes. In the third task the share increased to $69 \%$ for children with MID and only to $10 \%$ for intact children. The intact children made almost always only one mistake but children with MID made up to 3 mistakes.

\section{DISCUSSION}

Data collection for pupils with MID took place in special schools, where they learn from modified curricular documents. They have three times the time normally allocated for work activities, have better equipment (specialized workshops, etc.), and there is significantly less of them in classes, which could have been reflected positively in the results, i.e. in reducing the gap between MID pupils and intact pupils during school attendance. However, verification of this effect would require additional data collection, especially among the pupils integrated individually in regular schools in order to verify the potential impact of special education and integration.

Slower maturing of children with MID has probably an impact on reducing the differences between the two groups.

Stimulating school environment is another factor that may have an impact on reducing the differences. In comparison with the intact children, MID children often grow up in families with low socioeconomic status and lower income or live more often only with one parent. These characteristics do not appear only in the Czech Republic but usually are present also in other countries (e.g. US Department of Education In [1]). Consequently, some children with MID live in less stimulating environment, have worse example for verbal communication, spend their free time passively (e.g. watching TV), enjoy less leisure activities and the like. All this may lead to the children falling behind in terms of cognitive development and development of motoric skills. It is very important that schools and other institutions helping children with MID should try to identify these vulnerable children and to compensate for their deficits, including the development of motor skills.

All these factors may act on together and assessing their impact and significance of individual factors would have to be the subject of further research.

When evaluating the differences between the two groups of pupils, it is important to compare not only the speed of performing the tasks, but also its quality. The difference was not only in slower work on manual activities, but also in the occurrence of mistakes, which was significantly higher for children with MID. For the preparation for further education and future career, this difference is perhaps more important than the actual speed of performing the tasks.

\section{CONCLUSION}

Pupils with MID are likely to engage in normal adult life without the help of social services. For this to happen, it is important to prepare them for coping with demands of daily life 
and for their job. It is a matter-of-course that an intensive work on intellectual skills is needed (e.g. reading, practical numeracy, the use of modern technology, etc.). We must not forget that there are other areas (like manual skills), in which MID and intact children are seemingly at a similar level but in reality, they need a higher level of support also in these areas.

\section{REFERENCE}

[1] M. Beirne-Smith, J. R. Patton, S. H. Kim. Mental Retardation. New Jersey: Pearson, 2006. ISBN 0-13-118189-0

[2] Sammons Preston. Jebsen Taylor Hand Function Test. Bolingbrook: Sammons Preston

[3] Ulrich, D. A. Test of Gross Motor Development - Test Administration and Scoring Procedures. Austin, Texas

[4] Framework Education Programme for Elementary Education. [online] VUP: Prague, 2007 [cit. 2014-12-11]. available from: http://www.vuppraha.cz/wpcontent/uploads/2009/12/RVP_ZV_EN_final.pdf

[5] Rámcový vzdělávací program pro základní vzdělávání - př́loha upravující vzdělávání žáků s lehkým mentálním postižením. [online] VUP: Prague, 2005 [cit. 2014-12-11]. available from: http://www.vuppraha.cz/wp-content/uploads/2009/12/rvpzv-lmp.pdf

[6] World Health Organization. International Classification of Diseases, Chapter V - Mental and behavioral disorders. [online] version 2007 [cit. 2014-12-11]. available from: http://apps.who.int/classifications/apps/icd/icd10online/

[7] P. Zikl. Srovnání motorických dovedností žáků ZŠ praktických. In Speciální pedagogika. 2013, N. 4, ISSN 1211-2720

[8] P. Zikl, M. Maněnová, D. Kalusová. Manual abilities of children with mild mental disabilities as a prerequisite for the use of modern technology. In Recent researches in educational technologies (EDUCATION '11). Athens: World scientific and engineering academy and society, 2011, pp. 111-115, ISBN 978-1-61804-021-3. [cit. 2013-0925] Available from: http://www.wseas.us/elibrary/conferences/2011/Penang/EDU/EDU-17.pdf

[9] D. Kindrová. Komparace manuálních dovedností žáků základních škol praktických s žáky intaktními. Hradec Králové: Faculty of Education, University of Hradec Králové, 2014 